\title{
Ongoing epidemic of Mycoplasma pneumoniae infection in Jerusalem, Israel, 2010 to 2012
}

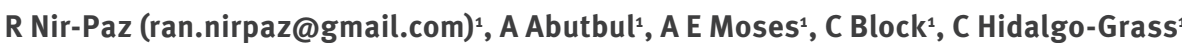

1. Department of Clinical Microbiology and Infectious Diseases, Hadassah-Hebrew University Medical Centers, Jerusalem, Israel

Nir-Paz R, Abutbul A, Moses AE, Block C, Hidalgo-Grass C. Ongoing epidemic of Mycoplasma pneumoniae infection in Jerusalem, Israel, 2010 to 2012.

Euro Surveill. 2012;17(8):pii=20095. Available online: http://www.eurosurveillance.org/ViewArticle.aspx?Articleld=20095

Article published on 23 February 2012

A substantial epidemic of Mycoplasma pneumoniae infection was reported in late 2011 in some European countries. We report here an epidemic of $M$. pneumoniae infection that began in Jerusalem during 2010 and is still ongoing. This report complements current information on what might be a worldwide epidemic of $M$. pneumoniae infection that might require substantial coordinated international public health intervention.

We describe here on an ongoing epidemic of Mycoplasma pneumoniae infection in Jerusalem, Israel, which started in February 2010. As of 31 January 2012, a total of 156 cases were identified among patients referred to the Hadassah-Hebrew University Medical Centers in Jerusalem.

\section{Background}

M. pneumoniae is one of the major leading respiratory bacterial pathogens, causing respiratory tract infections. It is known to cause epidemics that emerge at three-to-seven-year intervals and can last two years or more [1-3]. Until now, it was not clear whether this phenomenon was endemic to certain regions or was global in nature. Some reports have suggested that similar trends can be observed in adjacent countries [2,4-6]. Additionally, it has been suggested that most epidemics occur either in summer or autumn, without an evident explanation for this seasonal occurrence of M. pneumoniae outbreaks $[2,7,8]$.

During 2006 and 2007, an increase in the number of cases of $M$. pneumoniae infection was reported in several countries including England and Norway [3,9]. A new surge was noted in a few countries in 2010 , including England and Wales, Denmark and Israel $[3,10,11]$. In both Denmark and the United Kingdom, a decrease in the number of cases was reported in early 2011. However, a new surge of cases was noted in a few northern European countries by the end of 2011 and early $2012[2,4-6,9,12,13]$ and there were also reports of an increase in the number of cases in 2011 in Japan (M. Narita, personal communication, September 2011), which included the Emperor of Japan and his granddaughter [14].

One of the major obstacles to timely diagnosis of M. pneumoniae since its discovery 70 years ago has been the lack of a fast and reliable diagnostic method [15]. The past 20 years were notable for a revolution in the diagnosis of M. pneumoniae by direct DNA amplification methods, but only in the last few years, with the introduction of real-time $P C R$, has rapid diagnosis become more widely accessible.

\section{Setting}

The Hadassah-Hebrew University Medical Centers in Jerusalem provides most of the acute-care hospitalisation facilities in Jerusalem, with approximately 1,000 beds in two hospitals. It has secondary and tertiary facilities and provides, to a lesser extent, primary care consultation for some of the health maintenance organisations in Jerusalem. It currently serves a population over a million in Jerusalem and its surroundings.

Notification of $M$. pneumoniae infection is not mandatory in Israel and currently there is no laboratory in the Central Ministry of Health Laboratories to support its diagnosis. M. pneumoniae diagnostics based on DNA amplification were implemented almost 10 years ago at the Hadassah-Hebrew University Medical Centers [16], but real-time PCR was introduced only in late 2006 [11], at which point serological tests were discontinued. Physicians in all admission wards, mainly paediatrics and general medicine, can submit samples, with sameday results possible five days a week.

\section{Description of the epidemic}

The past few years saw the tail of a previous epidemic in 2007 and the abrupt onset of a new epidemic in February 2010 (Figure 1). A feature of this new epidemic was a relatively high percentage $(30 \%)$ of macrolideresistant $M$. pneumoniae isolates [11], but resistance rates may be diminishing as the epidemic progresses. It is still difficult to estimate the real extent of resistance at this stage since surveillance of resistance is only 
done periodically, every few months. Interestingly, no consistent seasonal or monthly influences were noted (Figure 2). The number of M. pneumoniae-positive samples fell from 2007, with almost no cases detected towards the end of the year, very few in 2008 and none in 2009. However, after the start of the 2010 epidemic - and unlike the phenomenon observed in Denmark [4] - there has been no notable decrease in the number of cases of M. pneumoniae infection, except for a temporary fall during early 2011. Since April 2011, a more or less constant number of new cases has been observed each month.

\section{FIGURE 1}

Mycoplasma pneumoniae-positive patients tested by realtime PCR referred to the Hadassah-Hebrew University Medical Centers, Jerusalem, Israel, 2007-2012a $(\mathrm{n}=180)$

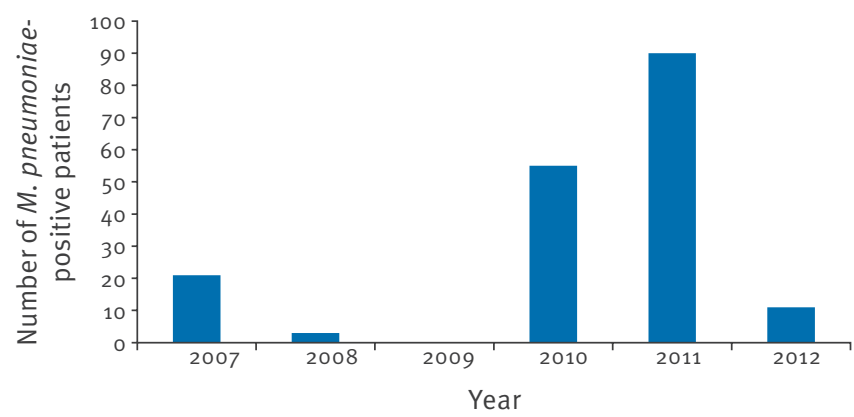

The total number of patient-unique samples submitted for M. pneumoniae diagnosis were: 189 in 2007, 150 in 2008; 223 in 2009, 343 in 2010, 539 in 2011 and 94 in January 2012.

a Data for 2012 include January only.
The demographic and clinical characteristics of 166 patients hospitalised at the Hadassah-Hebrew University Medical Centers during 2007 to January 2012, from whom clinical information was collected, are presented in the Table.

Since the introduction of real time-PCR, the proportion of $M$. pneumoniae-positive tests submitted to our laboratory during the epidemic years has been relatively stable: in 2007 it was $11.1 \%, 16.0 \%$ in $2010,16.7 \%$ in 2011 and $11.7 \%$ in January 2012. In the non epidemic years, it was low: $2 \%$ in 2008 and $0 \%$ in 2009.

\section{Discussion}

Of the major bacterial respiratory pathogens including Haemophilus influenzae and Streptococcus pneumoniae, M. pneumoniae is the only one for which no vaccine is available. $M$. pneumoniae is considered to cause a milder disease compared with $S$. pneumoniae, though substantial morbidity can be observed [17]. Indeed the median duration of admission in our cohort was four days.

In many laboratories, serology is still being used [2,6]. The resulting delay in diagnosis poses a problem for clinicians [2], who need to ensure prompt treatment of patients with $M$. pneumoniae infection. Problems in diagnosis have led to under-investigation in the past and have also impeded our ability to understand the epidemiology of the local outbreak setting as well as the nationwide or worldwide spread of this pathogen.

A study from Germany suggested that no single clone was responsible for nationwide $M$. pneumoniae infections [18]. Indeed, Chalker at al. suggested from multilocus variable number tandem repeat analysis (MLVA)

\section{FIGURE 2}

Mycoplasma pneumoniae-positive patients tested by real-time PCR, by month and year of referral to the Hadassah-Hebrew University Medical Centers, Jerusalem, Israel, during the epidemic years 2007, 2010-2012a $(\mathrm{n}=177)$

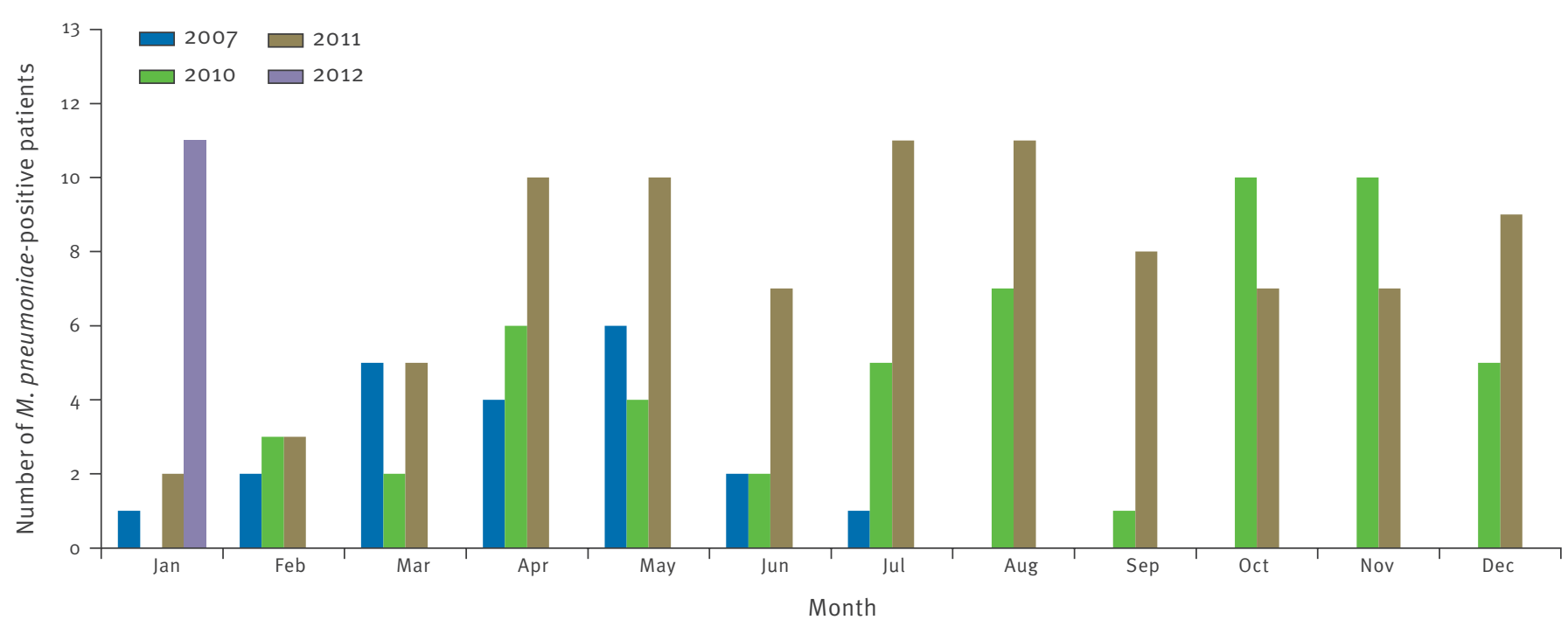

a Data for 2012 include January only. 
typing of a small sample in the United Kingdom that epidemics are multiclonal in nature [13]. In contrast, Pereyre et al. have evidence that a small outbreak in Bordeaux, France, might be related to a single clone [19]. In influenza, the epidemics generally involve a single or very few clones of influenza virus that spread worldwide at the same time. Interestingly, it seems that M. pneumoniae epidemics do occur worldwide and are a global phenomenon affecting countries both adjacent and distant. This is demonstrated by the fact that in 2007, epidemics were noted in several countries, some of which are not adjacent to each other [3,9], including Israel. Similar observations were made in 2010 and $2011[2,4-6,9,12-14]$. It seems that for unknown reasons some countries are spared from such epidemics [2]. For example countries in the south of western Europe are not affected by the current epidemic [2,6]. Additionally, the specific epidemiological pattern within each country seems to differ: in some countries the epidemic is abrupt and subsides relatively quickly [4], while, as in our case, the epidemic has so far being maintained for more than two years.

Our study has a few limitations. Being a single-institution study, selection bias in the population referred to our hospitals may have resulted in the inclusion of more severe cases, possibly with more underlying conditions or co-morbidities. In addition, since currently there is no nationwide surveillance programme for $M$. pneumoniae in Israel and no published data are available from other Israeli medical institutions, we do

\section{TABLE}

Characteristics of Mycoplasma pneumoniae-positive patients tested by real-time PCR referred to the HadassahHebrew University Medical Centers, Jerusalem, Israel, during the epidemic years, 2007-2012 ${ }^{\mathrm{a}}(\mathrm{n}=166)^{\mathrm{b}}$

\begin{tabular}{|c|c|}
\hline Characteristic & Details \\
\hline Age & Median: 12 years (range: $0.3-77$ ) \\
\hline Sex & $\begin{array}{l}98(59.0 \%) \text { male, } \\
68(41.0 \%) \text { female }\end{array}$ \\
\hline Ethnicity ${ }^{c}$ & $\begin{array}{l}41(24.7 \%) \text { Arabs, } \\
123(74.1 \%) \text { Jews }\end{array}$ \\
\hline Having underlying disease & $47(28.3 \%)$ \\
\hline $\begin{array}{l}\text { Did not improve on antibiotics } \\
\text { prescribed in the community }\end{array}$ & $73(44.0 \%)$ \\
\hline $\begin{array}{l}\text { Body temperature on } \\
\text { admission }\end{array}$ & Median: $37.5^{\circ} \mathrm{C}$ (range: $\left.35.8-40.1\right)$ \\
\hline Chest X-ray performed & $149(89.8 \%)$ \\
\hline $\begin{array}{l}\text { Infiltration compatible with } \\
\text { pneumonia on chest X-ray }\end{array}$ & $92 / 149(61.7 \%)$ \\
\hline $\begin{array}{l}\text { Bilateral pneumonia on } \\
\text { chest X-ray }\end{array}$ & $21 / 149(14.1 \%)$ \\
\hline $\begin{array}{l}\text { White blood cell count on } \\
\text { admission }\end{array}$ & $\begin{array}{l}\text { Median: } 9.8 \text { (range: } 1.2-37.4 \text { ) } \\
\text { x109/L }\end{array}$ \\
\hline Length of hospital stay & Median: 4 days (range: $0-50$ ) \\
\hline
\end{tabular}

a Data for 2012 include January only.

b Patients for whom data were available.

Two patients were not from Israel. not know the extent of the infection in the rest of the country.

Our report is in line with recent observations published in Eurosurveillance $[4-6,9,12,13]$ and emphasises the need to understand the epidemiology and pathogenesis of epidemics of $M$. pneumoniae infection better. To this end, it would be appropriate for countries to establish sentinel institutions equipped with up-to-date dedicated diagnostics for M. pneumoniae. A network of such facilities, working in a coordinated fashion, would provide invaluable information for epidemic and interepidemic periods.

\section{References}

1. Lind K, Benzon MW, Jensen IS, Clyde WA, Jr. A seroepidemiological study of Mycoplasma pneumoniae infections in Denmark over the 50-year period 1946-1995. Eur J Epidemiol. 1997;13(5):581-6.

2. Jacobs E. Mycoplasma pneumoniae: now in the focus of clinicians and epidemiologists. Euro Surveill. 2012;17(6): pii=20084. Available from: http://www. eurosurveillance.org/ViewArticle.aspx?Articleld=20084

3. Chalker VJ, Stocki T, Mentasti M, Fleming D, Sadler C, Ellis $J$, et al. Mycoplasma pneumoniae infection in primary care investigated by real-time PCR in England and Wales. Eur J Clin Microbiol Infect Dis. 2011;30(7):915-21.

4. Uldum SA, Bangsborg JM, Gahrn-Hansen B, Ljung R, Mølvadgaard M, Føns Petersen R, et al. Epidemic of Mycoplasma pneumoniae infection in Denmark, 2010 and 2011. Euro Surveill. 2012;17(5):pii=20073. Available from: http:// www.eurosurveillance.org/ViewArticle.aspx?Articleld $=20073$

5. Polkowska A, Harjunpää A, Toikkanen S, Lappalainen $M$, Vuento R, Vuorinen T, et al. Increased incidence of Mycoplasma pneumoniae infection in Finland, 2010-2011. Euro Surveill. 2012;17(5):pii=20072. Available from: http://www. eurosurveillance.org/ViewArticle.aspx?Articleld=20072

6. Lenglet A, Herrador Z, Magiorakos AP, Leitmeyer K, Coulombier D, European Working Group on Mycoplasma pneumoniae Surveillance. Surveillance status and recent data for Mycoplasma pneumoniae infections in the European Union and European Economic Area, January 2012. Euro Surveill. 2012;17(5):pii=20075. Available from: http://www. eurosurveillance.org/ViewArticle.aspx?Articleld=20075

7. Rastawicki W, Kaluzewski S, Jagielski M, Gierczyski R. Epidemiology of Mycoplasma pneumoniae infections in Poland: 28 years of surveillance in Warsaw 1970-1997. Euro Surveill. 1998;3(10):pii=95. Available online: http://www. eurosurveillance.org/ViewArticle.aspx?Articleld =95

8. Tjhie JH, Dorigo-Zetsma JW, Roosendaal R, Van Den Brule AJ, Bestebroer TM, Bartelds Al, et al. Chlamydia pneumoniae and Mycoplasma pneumoniae in children with acute respiratory infection in general practices in the Netherlands. Scand J Infect Dis. 2000;32(1):13-7.

9. Blystad H, Ånestad G, Vesteheim DF, Madsen S, Rønning K. Increased incidence of Mycoplasma pneumoniae infection in Norway 2011. Euro Surveill. 2012;17(5):pii=20074. Available from: http://www.eurosurveillance.org/ViewArticle. aspx?Articleld $=20074$

10. Rasmussen JN, Voldstedlund M, Andersen RL, EllermannEriksen S, Jensen TG, Johansen HK, et al. Increased incidence of Mycoplasma pneumoniae infections detected by laboratory-based surveillance in Denmark in 2010. Euro Surveill. 2010;15(45):pii=19708. Available from: http://www. eurosurveillance.org/ViewArticle.aspx?Articleld=19708

11. Averbuch D, Hidalgo-Grass C, Moses AE, Engelhard D, Nir-Paz R. Macrolide resistance in Mycoplasma pneumoniae, Israel, 2010. Emerg Infect Dis. 2011;17(6):1079-82.

12. Linde A, Ternhag A, Törner A, Claesson BE. Antibiotic prescriptions and laboratory-confirmed cases of Mycoplasma pneumoniae during the epidemic in Sweden in 2011. Euro Surveill. 2012;17(6):pii=20082. Available from: http://www. eurosurveillance.org/ViewArticle.aspx?Articleld $=20082$

13. Chalker VJ, Stocki T, Litt D, Bermingham A, Watson J, Fleming DM, et al. Increased detection of Mycoplasma pneumoniae infection in children in England and Wales, October 2011 to January 2012. Euro Surveill. 2012;17(6): pii=20081. Available 
from: http://www.eurosurveillance.org/ViewArticle. aspx?Articleld $=20081$

14. The Imperial Household Agency. Press conference on the occasion of His Majesty's birthday (2011). Tokyo: The Imperial Household Agency. [Accessed 21 Feb 2012]. Available from: http://www.kunaicho.go.jp/e-okotoba/o1/press/gokansoh23e.html

15. Atkinson TP, Balish MF, Waites KB. Epidemiology, clinical manifestations, pathogenesis and laboratory detection of Mycoplasma pneumoniae infections. FEMS Microbiol Rev. 2008;32(6):956-73.

16. Klement E, Talkington DF, Wasserzug O, Kayouf R, Davidovitch $N$, Dumke R, et al. Identification of risk factors for infection in an outbreak of Mycoplasma pneumoniae respiratory tract disease. Clin Infect Dis. 2006;43(10):1239-45.

17. Kannan TR, Hardy RD, Coalson JJ, Cavuoti DC, Siegel JD, Cagle $M$, et al. Fatal outcomes in family transmission of Mycoplasma pneumoniae. Clin Infect Dis. 2012;54(2):225-31.

18. Dumke R, von Baum H, Lück PC, Jacobs E. Subtypes and variants of Mycoplasma pneumoniae: local and temporal changes in Germany 2003-2006 and absence of a correlation between the genotype in the respiratory tract and the occurrence of genotype-specific antibodies in the sera of infected patients. Epidemiol Infect. 2010;138(12):1829-37.

19. Pereyre S, Renaudin H, Charron A, Bébéar C. Clonal spread of Mycoplasma pneumoniae in primary school, Bordeaux, France. Emerg Infect Dis. 2012;18(2):343-5. 